\title{
KOMPARASI ALGORITMA KLASIFIKASI SVM-PSO DAN C4.5-PSO DALAM PREDIKSI PENYAKIT JANTUNG
}

\author{
Weiskhy Steven Dharmawan \\ Universitas Bina Sarana Informatika \\ Jl Abdurahman Saleh No.18, 78124 \\ e-mail: weiskhy.wvn@bsi.ac.id
}

\begin{abstract}
ABSTRAK
Dalam analisis data untuk dataset yang berdimensi besar, klasifikasi sangat diperlukan dalam memprediksi dari sebuah dataset, dalam penelitian ini membandingkan suatu metode untuk mengklasifikasi data yang besar yang dimana data tesebut akan di olah untuk mendapatkan hasil informasi prediksi data yang di inginkan. Dalam penelitian ini Support Vector Machine (SVM) digunakan untuk memberikan hasil klasifikasi dari kinerja seleksi fitur yang dilakukan Particle Swarm Optimization (PSO) yang mana hasil pengujian nya akan di bandingkan dengan algoritma klasifikasi C4.5 sebagai pembanding algoritma mana yang lebih baik dalam memprediksi dari sebuah dataset. C4.5 digunakan juga untuk memberikan hasil klasifikasi yang di gabungan bersama Particle Swarm Optimization (PSO). Dari eksperimen yang di lakukan algoritma SVM-PSO mendapatkan nilai Accuracy $84.81 \%$ dan nilai AUCnya 0.898 sedangkan Algoritma C4.5-PSO mendapatkan nilai Accuracy $80.00 \%$ dan nilai AUCnya 0.787 .
\end{abstract}

Kata kunci : Support Vector Machine (SVM), Particle Swarm Optimization (PSO), Prediksi.

\begin{abstract}
In data analysis for large-dimensional datasets, classification is very necessary in predicting from a dataset, in this study comparing a method for classifying large data where the data will be processed to obtain the desired data prediction information. In this study the Support Vector Machine (SVM) is used to provide classification results from the feature selection performance carried out by Particle Swarm Optimization (PSO) where the test results will be compared with the C4.5 classification algorithm as a comparison which algorithm is better at predicting than the dataset. C4.5 is also used to provide classification results combined with Particle Swarm Optimization (PSO). From the experiments carried out, the SVM-PSO algorithm obtained an Accuracy value of $84.81 \%$ and an AUC value of 0.898 while the C4.5-PSO algorithm obtained an Accuracy value of $80.00 \%$ and an AUC value of 0.787 .
\end{abstract}

Keywords : Support Vector Machine (SVM), Particle Swarm Optimization (PSO), prediction

\section{PENDAHULUAN}

Dalam dunia kesehatan dan medis suatu keakuratan prediksi sebuah penyakit sangatlah penting dan memerlukan keputusan yang tepat dan efektif dalam mengambil suatu analisa dan keakuratan prediksi suatu penyakit yang diderita pasien, seperti hal nya juga pada penyakit jatung yang sangat membutuhkan ke akuratan dalam memprediksi suatu gejala yang ada.

Penyakit jantung (Hananta \& Muhammad, 2011) adalah terjadinya terganggunya keseimbangan antara suplai dan kebutuhan darah yang terjadi akibat penyumbatan pembuluh darah. Kematian akibat penyakit jantung mencapai 959.227 pasien, yakni 41,4 \% dari seluruh kematian atau setiap hari 2600 penduduk meninggal akibat penyakit jantung (Hananta \& Muhammad, 2011).

Metode prediksi penyakit jantung banyak diusulkan dengan mengunakan Genetic Algorithm, native bayes dan decision trees decision support nä̈ve bayes, Multilayer Perceptron (Khemphila \& Boonjing, 2011). 
IN F ORM T IK A

Jurnal Informatika, Manajemen dan Komputer, Vol. 13, No. 2, Desember 2021

eISSN : 2580-3042

pISSN : 1979-0694

Faktor gejala yang terdiagnosa sebagai penyakit jantung antara lain adalah jenis sakit dada (cheasr pain), tekanan darah tinggi (tresbps), kolesterol (chol), nilai tes EKG (resting electrodiagraphic "restacg")), denyut jantung (thalach) dan kadar gula (fasting blood sugar "FBS") (Mahmood \& Kuppa, 2010). Dan beberapa factor lainnya yang menindentifikasi bahwa seseorang mempunyai penyakit jantung.

Penyakit jantung meliputi aortic regurgition, cardiogenic shock, congenital heart disease, cardiomyopathy, peripartum cardiomyopa-thy, tricuspid regurgitation (Hananta \& Muhammad, 2011) yang sering menjangkit pada anak-anak, orang dewasa dan tetap menjadi masalah utama di Negara-negara berkembang.

Pada penelitian ini akan membandingkan dua algoritma klasifikasi Support Vector Machine (SVM) dan C4.5 yang dikombinasikan dengan Particle Swarm Optimization (PSO) untuk menentukan hasil mana yang lebih akurat dalam prediksi penyakit jantung lebih baik.

\section{METODOLOGI PENELITIAN \\ a. Data Mining}

Data Mining adalah suatu istilah yang digunakan untuk menemukan pengetahuan yang tersembunyi didalam database. Data Mining didefinisikan sebagai proses penemuan pola dalam data. Beberapa aplikasi data mining fokus pada prediksi, mereka meramalkan apa yang akan terjadi dalam situasi baru dari data yang menggambarkan apa yang terjadi di masa lalu (Witten et al., 2011). Secara khusus, koleksi metode yang dikenal sebagai data mining menawarkan metodologi dan solusi teknis untuk mengatasi analisis data medis dan konstruksi prediksi model.

Menurut Zafra dan Ventura (2012) data mining adalah proses penggalian pengetahuan yang berguna dan informasi dari kumpulan data. Saat ini data mining telah digunakan di banyak domain aplikasi seperti industri biomedis, ritel dan pemasaran, telekomunikasi, pertambangan web, audit komputer, industri keuangan, obatobatan dan seterusnya (Zaki et al., 2014).

\footnotetext{
Data mining juga didefinisikan suatu tindakan melakukan ekstraksi untuk mendapatkan informasi penting yang sifatnya implisit dan sebelumnya tidak diketahui, dari suatu data(Gorunescu, 2011). Data mining
}

merupakan sebuah teknik yang digunakan untuk beroperasi pada data yang memiliki volume besar untuk menemukan pola-pola yang tersembunyi dan mencari hubungan agar dapat digunakan untuk membantu dalam pengambilan keputusan.

Berdasarkan pengertian-pengertian di atas dapat di simpulkan bahwa data mining merupakan disiplin ilmu yang mempelajari metode untuk mengekstrak pengetahuan atau menemukan pola dari suatu data.

Data mining merupakan bagian dari proses Knowledge Discovery from Data (KDD). proses penjelajahan pengetahuan dimulai dari beberapa database dilakukan proses cleaning dan integration sehingga menghasilkan data warehouse. Dilakukan proses selection dan transformation yang kemudian disebut sebagai data mining hingga menemukan pola dan memperoleh pengetahuan dari data (knowledge).

Tahapan data mining dalam proses penemuan pengetahuan (Jiawei et al., 2012):

1. Pembersihan data (untuk menghilangkan noise dan data tidak konsisten)

2. Integrasi data (di mana beberapa sumber data dapat dikombinasikan)

3. Data seleksi (di mana data yang relevan dengan tugas analisis basis data yang akan diambil)

4. Data transformasi (dimana data diubah atau dikonsolidasikan ke dalam bentuk yang sesuai untuk pertambangan dengan melakukan operasi ringkasan atau agregasi)

5. Data mining (proses esensial dimana metode cerdas diaplikasikan untuk mengekstrak pola data)

6. Pola evaluasi (untuk mengidentifikasi pola yang benar-benar menarik yang mewakili pengetahuan didasarkan pada beberapa langkah-langkah interestingness)

7. Pengetahuan presentasi (dimana visualisasi dan teknik representasi pengetahuan digunakan untuk menyajikan pengetahuan ditambang kepada pengguna)

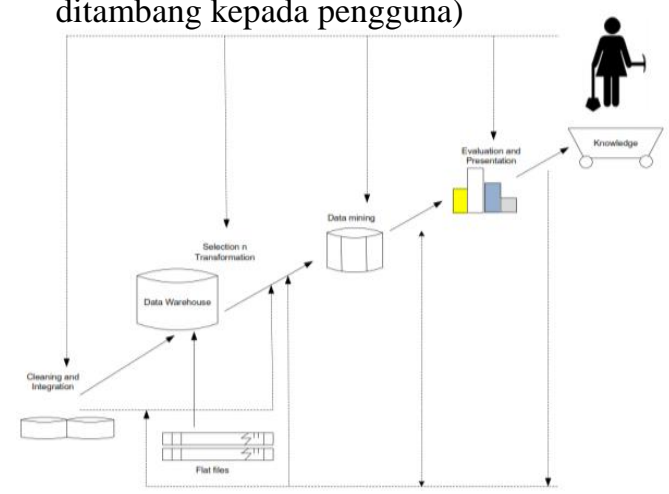

Gambar 1: Tahapan data mining 
INFORM T IK

Jurnal Informatika, Manajemen dan Komputer, Vol. 13, No. 2, Desember 2021

eISSN : 2580-3042

pISSN : 1979-0694

\section{b. Support Vector Machine (SVM)}

Support Vector Machine adalah metode learning machine yang bekerja atas prinsip Structural Risk Minimization (SRM) dengan tujuan menemukan hyperplane terbaik yang memisahkan dua buah class pada input space. Hyperplane terbaik adalah hyperplane yang terletak ditengah-tengah antara dua set obyek dari dua class. Hyperplane pemisah terbaik antara kedua class dapat ditemukan dengan mengukur margin hyperplane tersebut dan mencari titik maksimalnya. Margin adalah jarak antara hyperplane tersebut dengan pattern terdekat dari masing-masing class. Pattern yang paling dekat ini disebut sebagai support vector (Lee \& Lee, 2015).

Menurut Y. Yin, Han, \& Cai, (2011) Support Vector Machine (SVM) didefinisikan sebagai seperangkat metode pembelajaran terkait yang menganalisis data dan mengenali pola, yang kemudian digunakan untuk klasifikasi dan analisis regresi. SVM mengambil satu set data input dan memprediksi untuk setiap masukan yang diberikan, yang berasal dari dua kelas yang kemudian di klasifikasikan dengan mencari nilai hyperplane terbaik.

Menurut (Yin et al., 2011) Support Vector Machine (SVM) adalah suatu metode klasifikasi untuk mencari nilai hyperplane terbaik yang mampu menemukan solusi global optimal. Sehingga nilai akurasi tidak mudah berubahubah.

Menurut Li, Support Vector Machine (SVM) merupakan pembelajaran yang mengarah ke pemrograman kuadratik dengan kendala linear. Berdasarkan minimalisasi risiko prinsip terstruktur, SVM berusaha untuk meminimalkan batas atas kesalahan generalisasi bukan kesalahan empiris, sehingga model prediksi baru efektif menghindari over-pas masalah. Selain itu, model SVM bekerja di ruang fitur berdimensi tinggi yang dibentuk oleh pemetaan nonlinear dari $\mathrm{N}$ dimensi vektor input $\mathrm{x}$ ke dalam ruang fitur $\mathrm{K}$ dimensi $(\mathrm{K}>\mathrm{N})$ melalui penggunaan fungsi $\varphi$ nonlinear (x)(Liu et al., 2011).

Berdasarkan pengertian di atas dapat disimpulkan Support Vector Machine (SVM) merupakan suatu metode klasifikasi yang memaksimalkan batas hyperplane (maximal margin hyperplane). Jika dalam ANN semua data latih akan dipelajari selama proses pelatihan, sedangkan pada SVM berbeda karena hanya sejumlah data terpilih saja yang berkontribusi untuk membentuk model yang digunakan dalam klasifikasi yang akan dipelajari (Yu et al., 2011). Hal ini menjadi kelebihan SVM karena tidak semua data latih akan di pandang untuk dilibatkan dalam setiap iterasi pelatihannya. Data-data yang berkontribusi tersebut disebut sebagai support vector sehingga metodenya disebut Support Vector Machine.

Yang menjadi karakteristik dari Support Vector Machine (SVM) adalah sebagai berikut:

1. Secara prinsip SVM adalah linear classifier.

2. Pattern recognition dilakukan dengan mentransformasikan data pada input space ke ruang yang berdimensi lebih tinggi, dan optimisasi dilakukan pada ruang vector yang baru tersebut. Hal ini membedakan SVM dari solusi pattern recognition pada umumnya, yang melakukan optimisasi parameter pada ruang hasil transformasi yang berdimensi lebih rendah daripada dimensi input space.

3. Menerapkan strategi Structural Risk Minimization (SRM).

4. Prinsip kerja SVM pada dasarnya hanya mampu menangani klasifikasi dua kelas.

Secara sederhana konsep SVM adalah sebagai usaha mencari hyperlane terbaik yang berfungsi sebagai pemisah dua buah class pada input space, dimana dapat dilihat pada gambar dibawah ini:
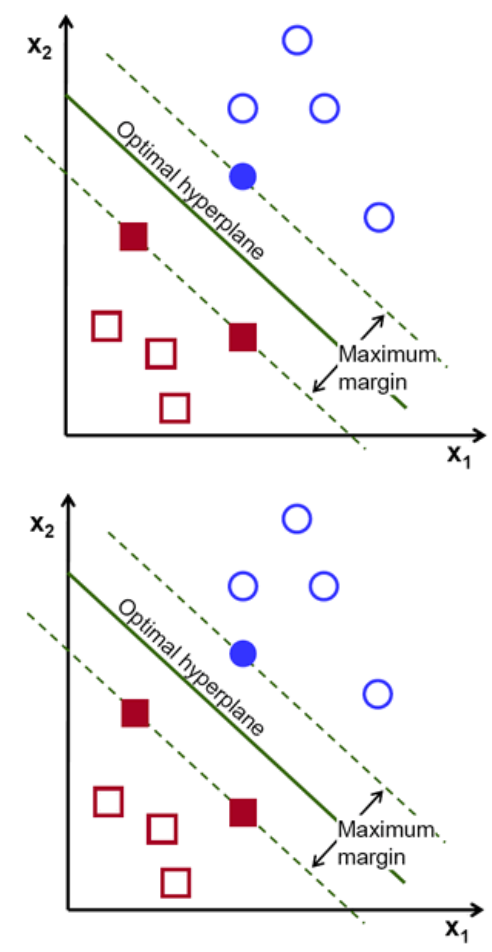

Gambar 2: Konsep SVM untuk mencari hyperlane terbaik 
IN F ORM T IK A

Jurnal Informatika, Manajemen dan Komputer, Vol. 13, No. 2, Desember 2021

eISSN : 2580-3042

pISSN : 1979-0694

Gambar diatas memperlihatkan beberapa pola yang merupakan anggota dari dua buah kelas data : +1 dan -1 . Data yang tergabung pada kelas -1 disimbolkan dengan bentuk lingkaran, sedangkan data pada kelas +1 disimbolkan dengan bentuk bujur sangkar.

Hyperplane (batas keputusan) pemisah terbaik antara kedua kelas dapat ditemukan dengan mengukur margin hyperplane tersebut dan mencari titik maksimalnya. Margin adalah jarak antara hyperplane tersebut dengan data terdekat dari masing-masing kelas. Data yang paling dekat ini disebut support vector. Garis solid pada gambar di atas menunjukkan hyperplane yang terbaik, yaitu yang terletak tepat pada tengah-tengah kedua kelas, sedangkan data lingkaran dan bujur sangkar yang dilewati garis batas margin (garis putus-putus) adalah support vector. Usaha untuk mencari lokasi hyperplane ini merupakan inti dari peoses pelatihan Support Vector Machine (SVM) (Prasetyo, 2012).

Data yang tersedia dinotasikan sebagai $\mathrm{x}$ $\in \mathrm{R}^{\mathrm{d}}$ sedangkan label masing-masing dinotasikan yi $\in\{-1+1\}$ untuk $i=1,2, \ldots ., 1$ yang mana 1 adalah banyaknya data. Diasumsikan kedua class -1 dan +1 dapat terpisah secara sempurna oleh hyperplane berdimensi d, yang didefinisikan:

$$
\mathrm{w} \cdot \mathrm{x}+\mathrm{b}=0
$$

Sebuah pattern xi yang termasuk class 1 (sampel negatif) dapat dirumuskan sebagai pattern yang memenuhi pertidaksamaan:

$$
\text { - } \quad \text { w. } x+b=-1
$$

sedangkan pattern yang termasuk class +1 (sampe 1 positif):

$$
\text { - } \quad \text { w. } x+b=+1
$$

Margin terbesar dapat ditemukan dengan memaksimalkan nilai jarak antara hyperplane dan titik terdekatnya, yaitu $1 /\|w\|$. Hal ini dapat dirumuskan sebagai Quadratic Programming (QP) problem, yaitu mencari titik minimal persamaan, dengan memperhatikan constraint persamaan.

$$
\begin{aligned}
& \frac{\min }{w} t(w)=\frac{1}{2}\|w\|^{2} \\
& \text { yi(xi.w+b) }-1 \geq 0, \forall_{\mathrm{i}}
\end{aligned}
$$

Problem ini dapat dipecahkan dengan berbagai teknik komputasi, diantaranya Lagrange Multiplier :

$$
\begin{array}{r}
L(w, b, \alpha)=\frac{1}{2}\|w\|^{2} w \sum_{i=1}\left(\alpha_{i}\right)\left(y _ { i } \left(\left(x_{i} . w\right.\right.\right. \\
+b)-1))(i=1,2, \ldots, 1)
\end{array}
$$

$\alpha \mathrm{i}$ adalah Lagrange multipliers, yang bernilai nol atau positif ( $\alpha \mathrm{i} 0)$. Nilai optimal dari persamaan (2.6) dapat dihitung dengan meminimalkan L terhadap $\mathrm{w}$ dan $\mathrm{b}$, dan memaksimalkan $\mathrm{L}$ terhadap $\alpha$ i. Dengan memperhatikan sifat bahwa pada titik optimal gradient $\mathrm{L}=0$, persamaan langkah 2.6 dapat dimodifikasi sebagai maksimalisasi problem yang hanya mengandung saja $\alpha$ i, sebagaimana persamaan 2.7.

Maximize $: \sum_{i=1} \alpha_{i}$

$$
\frac{1}{2} \sum_{i . j=1}^{1} \alpha_{i}, a_{j}, y_{i}, y_{j}, x_{i},-,-x_{j}
$$

$$
\text { (2.13) }
$$

Subject to:

$$
\alpha_{i} \geq 0(i=1,2, \ldots, 1) \sum_{i=1}^{1} \alpha_{i} y_{i}=0
$$

Dari hasil dari perhitungan ini diperoleh ai yang kebanyakan bernilai positif. Data yang berkorelasi dengan $\alpha$ i yang positif inilah yang disebut sebagai support vector. Sebagai contoh digunakan problem AND. Problem AND adalah klasifikasi dua kelas dengan empat data (lihat Tabel 2.1). Karena ini problem linier, kernelisasi tidak diperlukan.

Tabel 1 : AND Problem

\begin{tabular}{|c|c|c|}
\hline $\mathbf{X 1}$ & $\mathbf{X 2}$ & $\mathbf{Y}$ \\
\hline $\mathbf{1}$ & 1 & 1 \\
\hline $\mathbf{- 1}$ & 1 & -1 \\
\hline $\mathbf{1}$ & -1 & -1 \\
\hline $\mathbf{- 1}$ & -1 & -1 \\
\hline
\end{tabular}

dapatkan formulasi masalah optimisasi sebagai berikut:

$\min \frac{1}{2}\left(w \frac{2}{1}+w \frac{2}{2} w\right)+C\left(t_{1}+t_{2}+t_{3}+t_{4}\right)$

Subject to :

$\mathrm{w} 1+\mathrm{w} 2+\mathrm{b}+\mathrm{t} 1 \geq 1$

$\mathrm{w} 1-\mathrm{w} 2-\mathrm{b}+\mathrm{t} 2 \geq 1$

$-\mathrm{w} 1+\mathrm{w} 2-\mathrm{b}+\mathrm{t} 3 \geq 1$

$\mathrm{w} 1+\mathrm{w} 2-\mathrm{b}+\mathrm{t} 4 \geq 1$

$\mathrm{t} 1, \mathrm{t} 2, \mathrm{t} 3, \mathrm{t} 4 \geq 0$ 
IN F ORM A I I A

Jurnal Informatika, Manajemen dan Komputer, Vol. 13, No. 2, Desember 2021

eISSN : 2580-3042

pISSN : 1979-0694

Karena fungsi AND adalah kasus klasifikasi linier, maka bisa dipastikan nilai variable slack ti $=0$. Jadi Kita bisa masukkan nilai $\mathrm{C}=0$. Setelah menyelesaikan problem optimasi di atas didapat solusi

$$
\mathrm{w} 1=1, \mathrm{w} 2=1, \mathrm{~b}=-1
$$

Persamaan fungsi pemisahnya adalah

$$
f(x)=x 1+x 2-1 \text {. }
$$

Untuk menentukan output atau label dari setiap titik data/obyek kita gunakan fungsi $\mathrm{g}(\mathrm{x})=$ $\operatorname{sign}(\mathrm{x})$. Dengan fungsi sign ini semua nilai $\mathrm{f}(\mathrm{x})<0$ diberi label -1 dan lainnya diberi label +1 .

Metodologi penelitian berisi bagan kerangka penelitian serta penjelasan dari bagan kerangka penelitian tersebut.

\section{c. $\mathbf{C} 4.5$}

Algoritma data mining C4.5 merupakan sebuah algoritma yang diperuntukan untuk melakukan klasifikasi atau segmentasi pengelompokan yang bersifat prediktif. Klasifikasi merupakan salah satu proses pada data mining yang bertujuan untuk menemukan pola yang berharga dari data yang berukuran relatif besar hingga sangat besar

\section{d. Particle Swarm optimization (PSO)}

Particle Swarm Optimization (PSO) merupakan teknik optimasi heuristic global yang diperkenalkan oleh Dokter Kennedy dan Eberhart pada tahun 1995 yang terinspirasi oleh perilaku sosial kawanan burung yang mencoba mencapai tujuan yang tidak di ketahui (Kim et al., 2012). Particle Swarm Optimization (PSO) adalah jenis algoritma kecerdasan yang mampu melakukan optimasi terhadap sebuah variable terkait yang paling efektif.

Menurut Liu, Particle Swarm Optimization (PSO) adalah perhitungan evolusi Teknik. Serupa dengan algoritma genetika, PSO adalah sebuah alat optimasi. Hal ini terinspirasi oleh perilaku sosial di antara individu. Partikel (individu) yang mewakili potensi solusi masalah bergerak melalui ruang pencarian n-dimensi. Setiap partikel i memelihara catatan posisi kinerja terbaik dalam vektor yang disebut pbest (Liu et al., 2011).

Menurut Y. Yin et al., (2011) Particle Swarm Optimization (PSO) adalah metode komputasi yang mengoptimalkan masalah dengan iteratif untuk meningkatkan solusi kandidat berkaitan dengan ukuran tertentu kualitas. Gerakan setiap partikel dipengaruhi oleh posisi lokal yang dipandu menuju posisi paling dikenal dalam pencarian ruang, yang diperbarui sebagai posisi yang lebih baik dari partikel lain(Yin et al., 2011). Particle Swarm Optimization (PSO) juga merupakan teknik komputasi evolusioner yang mampu menghasilkan solusi secara global optimal dalam ruang pencarian melalui interaksi individu dalam segerombolan partikel. Setiap partikel menyampaikan informasi berupa posisi terbaiknya kepada partikel yang lain dan menyesuaikan posisi dan kecepatan masingmasing berdasarkan informasi yang diterima mengenai posisi yang terbaik tersebut.

Particle Swarm Optimization (PSO) adalah alat untuk menangani masalah optimasiWalaupun relatif baru, sudah banyak yang mengaplikasikan algoritma PSO, karena cukup sederhana serta memiliki kecepatan komputasi yang lebih cepat di bandingkan dengan algoritma optimasi lain nya seperti Genetic Algorithm (GA). Setiap partikel dalam PSO juga dikaitkan dengan kecepatan partikel terbang melalui ruang pencarian dengan kecepatan yang dinamis disesuaikan untuk perilaku histori mereka. Oleh karena itu, partikel memiliki kecenderungan untuk terbang menuju daerah pencarian yang lebih baik selama proses pencarian.

Berdasarkan pengertian di atas dapat disimpulkan bahwa Particle Swarm Optimization (PSO) merupakan metode optimasi yang mampu mengoptimalkan variable terdekat untuk mencapai akurasi yang maksimal.

Swarm Intelligence (SI) adalah sebuah paradigma cerdas terdistribusi inovatif untuk memecahkan masalah optimasi yang awalnya mengambil inspirasi dari contoh biologis dengan berkerumun, berkelompok dan menggiring fenomena dalam hewan vertebrata. Particle Swarm Optimization (PSO) menggabungkan perilaku berkerumun yang dilakukan hewan contoh dalam kawanan burung, sekelompok ikan, atau kawanan lebah, dan perilaku sosial pada manusia(Abraham et al., 2006)

Untuk menemukan solusi yang optimal, maka setiap partikel akan bergerak kearah posisi yang terbaik sebelumnya (pbest) dan posisi terbaik secara global (gbest). Sebagai contoh, partikel ke- $\mathrm{i}$ dinyatakan sebagai : $\mathrm{x}_{\mathrm{i}}=\left(\mathrm{x}_{\mathrm{i}}, 1, \mathrm{x}_{\mathrm{i}}, 2 \ldots\right.$ $\mathrm{x}$-i,d) dalam ruang d-dimensi. Posisi terbaik sebelumnya dari partikel ke- i disimpan dan dinyatakan sebagai pbest $_{i}=\left(\right.$ pbest $_{i, 1}$, pbest $_{i, 2}, \ldots$ pbest $_{i, d}$ ). Modifikasi kecepatan dan posisi tiap 
IN F ORM A I I A

Jurnal Informatika, Manajemen dan Komputer, Vol. 13, No. 2, Desember 2021

eISSN : 2580-3042

pISSN : 1979-0694

partikel dapat dihitung menggunakan kecepatan saat ini dan jarak pbest $t_{i, d}$ ke pbest $_{d}$ seperti ditunjukkan oleh persamaan berikut:

$v_{i, m}=w \cdot v_{i, m}+c_{1} * R *\left(\right.$ pbest $\left._{i, m}-x_{i, m}\right)+c_{2} * R *$

$\left(\right.$ gbest $\left._{m}-x_{i, m}\right)$

$x_{i d}=x_{i, m}+v_{i, m}$

Dimana:

n : jumlah partikel dalam kelompok

d : dimensi

$\mathrm{v}_{\mathrm{i}, \mathrm{m}} \quad$ : kecepatan partikel ke-i pada iterasi ke-

i

w : faktor bobot inersia

$\mathrm{c}_{1}, \mathrm{c}_{2} \quad$ : konstanta akeselerasi (learning rate)

$\mathrm{R}$ : bilangan random $(0-1)$

$\mathrm{x}_{\mathrm{i}, \mathrm{d}} \quad$ : posisi saat ini dari partikel ke- $\mathrm{i}$ pada

iterasi ke- $\mathrm{i}$

pbest $_{\mathrm{i}} \quad$ : posisi terbaik sebelumnya dari partikel

ke- $\mathrm{i}$

gbest : partikel terbaik diantara semua partikel dalam satu kelompok atau populasi

Rumusan di atas menghitung kecepatan baru untuk tiap partikel (solusi potensial) berdasarkan pada kecepatan sebelumnya $\left(\mathrm{V}_{\mathrm{i}, \mathrm{m}}\right)$, lokasi partikel dimana nilai fitness terbaik telah dicapai (pbest), dan lokasi populasi global (gbest untuk versi global, lbest untuk versi local) atau local neigh borhood pada algoritma versi local dimana nilai fitness terbaik telah dicapai.

Persamaan rumus selanjutnya memperbaharui posisi tiap partikel pada ruang solusi. Dua bilangan acak $c_{1}$ dan $c_{2}$ dibangkitkan sendiri. Penggunaan berat inersia $w$ telah memberikan performa yang meningkat pada sejumlah aplikasi.Secara garis besar, struktur dasar dari PSO dapat digambarkan dalam bagan dibawah ini:

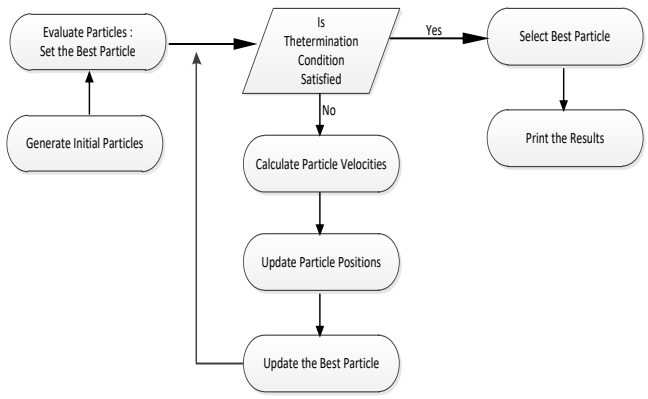

Gambar 3: Struktur dasar PSO 
I N F ORM A I I A

Jurnal Informatika, Manajemen dan Komputer, Vol. 13, No. 2, Desember 2021

eISSN : 2580-3042

pISSN : 1979-0694

Tabel 2: Confusion Matrix

\begin{tabular}{|c|c|c|c|}
\hline Clarifica & \multicolumn{3}{|c|}{ Predicted Class } \\
\hline \multirow{3}{*}{$\begin{array}{l}\text { Observe } \\
\mathrm{d} \\
\text { Class }\end{array}$} & & Class $=$ Yes & $\begin{array}{l}\text { Class = } \\
\text { No }\end{array}$ \\
\hline & $\begin{array}{c}\text { Class }= \\
\text { Yes }\end{array}$ & $\begin{array}{c}\mathrm{a} \\
\text { (True Positive }-\mathrm{TP} \text { ) }\end{array}$ & $\begin{array}{c}\mathrm{b} \\
\text { (Fals } \\
\text { Negati } \\
\text { ve - } \\
\text { FN) }\end{array}$ \\
\hline & $\begin{array}{c}\text { Class }= \\
\text { No }\end{array}$ & $\begin{array}{c}c \\
(\text { Fals Positive }- \text { FP) }\end{array}$ & $\begin{array}{c}\mathrm{d} \\
\text { (True } \\
\text { Negati } \\
\mathrm{ve}- \\
\mathrm{TN} \text { ) }\end{array}$ \\
\hline
\end{tabular}

Keterangan:

True Positive $(\mathrm{TP}) \quad=$ proporsi positif dalam data set yang diklasifikasikan positif

True Negative $(\mathrm{TN})=$ proporsi negative dalam data set yang diklasifikasikan negative

False Positive (FP) = proporsi negatif dalam data set yang diklasifikasikan potitif

False Negative $(\mathrm{FN}) \quad=$ proporsi negative dalam data set yang diklasifikasikan negatif

Berikut adalah persamaan model Confusion matrix :

a. Nilai Accuracy adalah proporsi jumlah prediksi yang benar. Dapat dihitung dengan menggunakan persamaan:

Accuracy $=\mathrm{TP}+\mathrm{TN}$

$$
\mathrm{TP}+\mathrm{TN}+\mathrm{FP}+\mathrm{FN}
$$

b. Sensitivity digunakan untuk membandingkan proporsi TP terhadap tupel yang positif, yang dihitung dengan menggunakan persamaan:

Sensitivity $=\quad \mathrm{TP}$

$$
\mathrm{TP}+\mathrm{FN}
$$

c. Specificity digunakan untuk membandingan proporsi TN terhadap tupel yang negatif, yang dihitung dengan menggunakan persamaan: Specificity $=\mathrm{TN}$

$$
\mathrm{TN}+\mathrm{FP}
$$

d. PPV (positive predictive value) adalah proporsi kasus dengan hasil diagnosa positif,

$$
\begin{aligned}
& \text { yang dihitung dengan menggunakan } \\
& \text { persamaan: } \\
& \mathrm{PPV}=\frac{\mathrm{TP}}{\mathrm{TP}+\mathrm{FP}}
\end{aligned}
$$

e. NPV (negative predictive value) adalah proporsi kasus dengan hasil diagnosa negatif, yang dihitung dengan menggunakan persamaan:

$$
\mathrm{NPV}=\frac{\mathrm{TN}}{\mathrm{TN}+\mathrm{FN}}
$$

\section{f. Kurva ROC}

Kurva ROC (Receiver Operating Characteristic) atau yang biasa disebut nilai AUC adalah alat visual yang berguna untuk membandingkan dua model klasifikasi. ROC mengekspresikan Confusion matrix. ROC adalah grafik dua dimensi dengan false positives sebagai garis horisontal dan true positives sebagai garis vertikal. Dengan kurva ROC, kita dapat melihat trade off antara tingkat dimana suatu model dapat mengenali tuple positif secara akurat dan tingkat dimana model tersebut salah mengenali tuple negatif sebagai tuple positif. Sebuah grafik ROC adalah plot dua dimensi dengan proporsi positif salah (fp) pada sumbu $X$ dan proporsi positif benar (tp) pada sumbu Y. Titik $(0,1)$ merupakan klasifikasi yang sempurna terhadap semua kasus positif dan kasus negatif. Nilai positif salah adalah tidak ada $(\mathrm{fp}=0)$ dan nilai positif benar adalah tinggi $(\mathrm{tp}=1)$. Titik $(0,0)$ adalah klasifikasi yang memprediksi setiap kasus menjadi negatif $\{-1\}$, dan titik $(1,1)$ adalah klasifikasi yang memprediksi setiap kasus menjadi positif $\{1\}$. Grafik ROC menggambarkan trade-off antara manfaat (true positive) dan biaya (false positives). Berikut tampilan dua jenis kurva ROC (discrete dan continous).

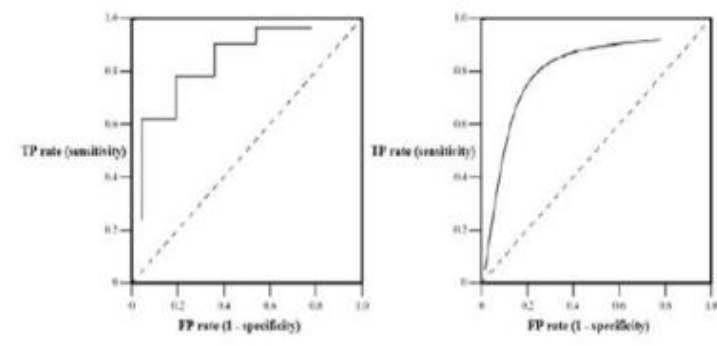

Gambar 5: Grafik ROC (discrete dan continuous) 
IN F O RM A I I A

Jurnal Informatika, Manajemen dan Komputer, Vol. 13, No. 2, Desember 2021

eISSN : 2580-3042

pISSN : 1979-0694

Poin diatas garis diagonal merupakan hasil klasifikasi yang baik, sedangkan point dibawah garis diagonal merupakan hasil klasifikasi yang buruk. Dapat disimpulkan bahwa, satu point pada kurva ROC adalah lebih baik dari pada yang lainnya jika arah garis melintang dari kiri bawah ke kanan atas didalam grafik. Untuk tingkat akuransi nilai AUC dalam klasifikasi data mining dibagi menjadi lima kelompok (Gorunescu, 2011), yaitu:

a. $0.90-1.00=$ klasifikasi sangat baik (excellent classification)

b. $0.80-0.90=$ klasifikasi baik $(\operatorname{good}$ classification)

c. $0.70-0.80=$ klasifikasi cukup (fair classification)

d. $0.60-0.70=$ klasifikasi buruk (poor classification)

$0.50-0.60=$ klasifikasi salah (failure)

\section{HASIL DAN PEMBAHASAN}

Penelitian merupakan kegiatan pemecahan masalah yang sistematis, yang dilakukan dengan perhatian dan kepedulian dalam konteks situasi yang dihadapi, penelitian dalam akademik digunakan untuk mengacu pada aktivitas yang rajin dan penyelidikan sistematis atau investigasi di suatu daerah, dengan tujuan menemukan atau merevisi fakta, teori, aplikasi dan tujuannya adalah untuk menemukan dan menyebarkan pengetahuan baru

Penelitian ini menggunakan metode penelitian eksperimen, yakni melibatkan dataset Heart statlog. Heart statlog sebuah database jantung yang memiliki variabel yang harus diperediksi apakah memiliki kejala penyakit jantung atau tidak.

\section{a. Pengujian metode Support Vector Machine (SVM) dan Particle Swarm Optimization (PSO)}

Berikut adalah hasil pengujian Support Vector Machine dan Particle swarm optimization yang menggunakan metode Cross Validation dengan menggunakan RapidMiner.

Hasil dan pembahasan berisi tentang pembahasan serta hasil akhir atau output program atau analisa metode dari penelitian tersebut.

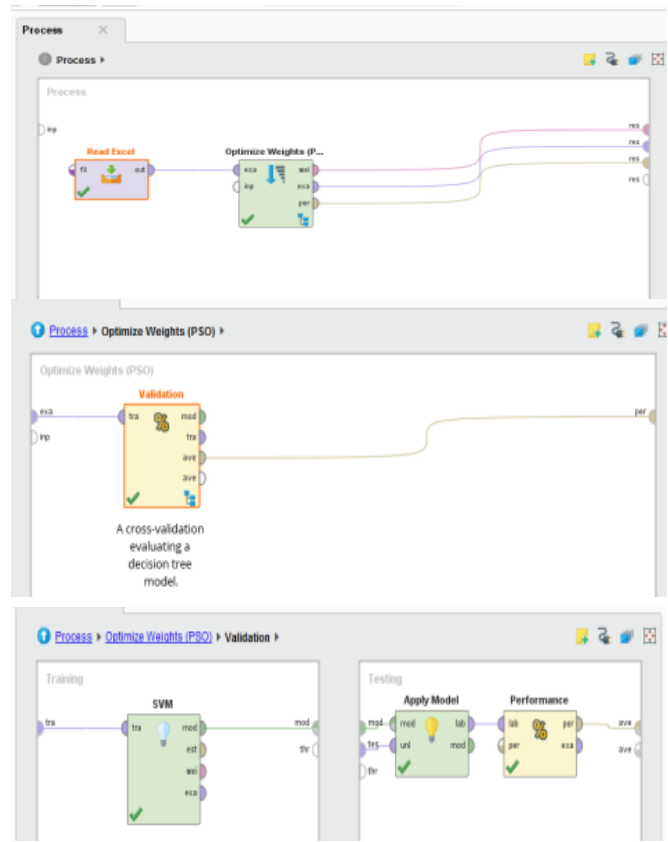

Gambar 6: Penerapan pola Support Vector Machine Particle Swarm dan Optimization dengan menggunakan Rapid Miner

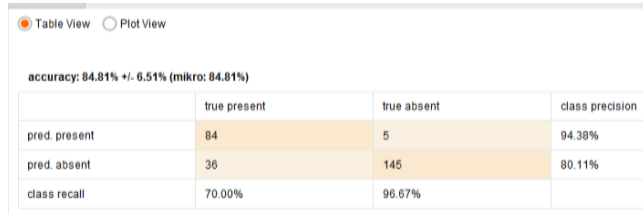

Gambar 7 :Hasil Nilai Accuracy SVM-PSO
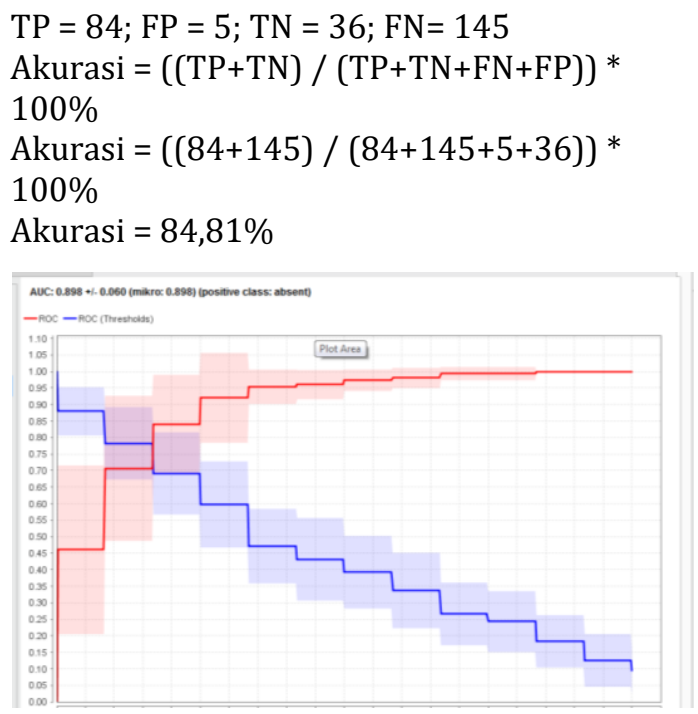

Gambar 8: Hasil Pengujian SVM-PSO berdasarkan nilai AUC 
INF ORM T IK A

Jurnal Informatika, Manajemen dan Komputer, Vol. 13, No. 2, Desember 2021

eISSN : 2580-3042

pISSN : 1979-0694

Dari hasil pengujian SVM-PSO dari dataset haert statlog pada gambar 7 dan 8 . Diperoleh dengan hasil nilai accuracy $84,81 \%$ dan AUCnya 0.898, Maka nilai tersebut yang akan digunakan dalam penelitian ini. Berdasarkan pengelompokan klasifikasi data mining menurut Gorunescu Florin, hasil penyelesaian klasifikasi yang dilakukan SVMPSO dengan dataset haert statlog memiliki nilai AUC antara 0.80-0.90 dengan arti klasifikasi baik (good classification).

o Table view OPlot view

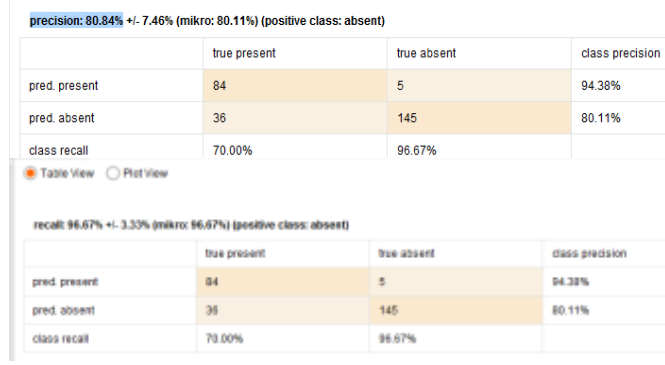

Gambar 9 : Hasil Pengujian Nilai Precision, Recall dari algoritma SVM-PSO

Hasil yang ditunjukan pada gambar 9. Menunjukan evaluasi kinerja metode yang diusulkan dilakukan dengan menghitung parameter uji berupa precision dengan nilai $80.84 \%$, recall dengan nilai $96.67 \%$ dihitung dengan menggunakan rumus:

Precision $=\frac{t p}{t p+f n}$

Recall $=\frac{t p}{t p+f p}$

1) Pengujian metode C4.5 dan Particle Swarm Optimization (PSO)

Berikut adalah hasil pengujian $C 4.5$ dan Particle swarm optimization yang menggunakan metode Cross Validation dengan menggunakan RapidMiner.

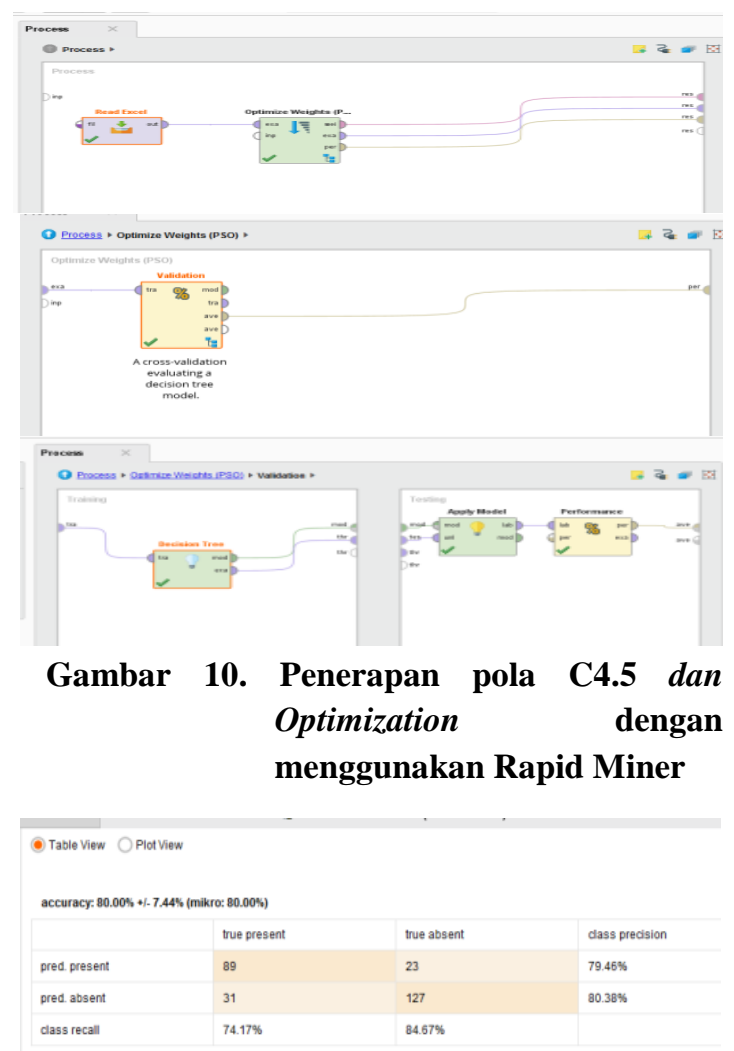

Gambar 11. Hasil Nilai Accuracy C4.5-PSO

$\mathrm{TP}=89 ; \mathrm{FP}=23 ; \mathrm{TN}=31 ; \mathrm{FN}=127$
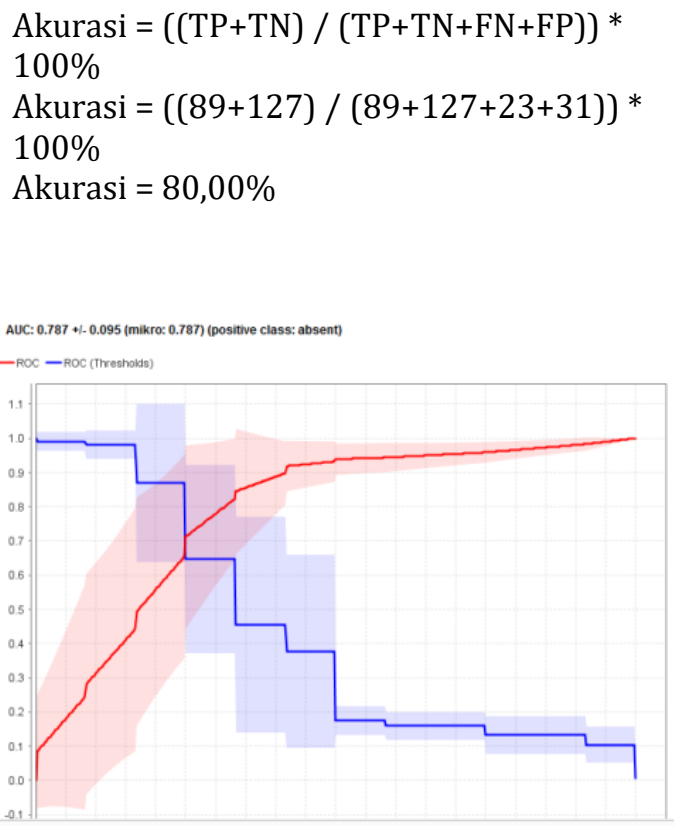

Gambar 12. Hasil Pengujian C4.5-PSO berdasarkan nilai AUC 
IN F ORM T I K A

Jurnal Informatika, Manajemen dan Komputer, Vol. 13, No. 2, Desember 2021

elSSN : 2580-3042

pISSN : 1979-0694

Dari hasil pengujian C4.5-PSO dari dataset haert statlog diperoleh pada gambar 11 dan 12 dengan hasil nilai accuracy $80.00 \%$ dan AUCnya 0.787, Maka nilai tersebut yang akan digunakan dalam penelitian ini. Berdasarkan pengelompokan klasifikasi data mining menurut Gorunescu Florin, hasil penyelesaian klasifikasi yang dilakukan C4.5-PSO dengan dataset haert statlog memiliki nilai AUC antara 0.70 - 0.80

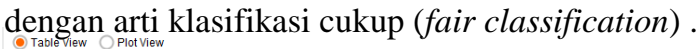

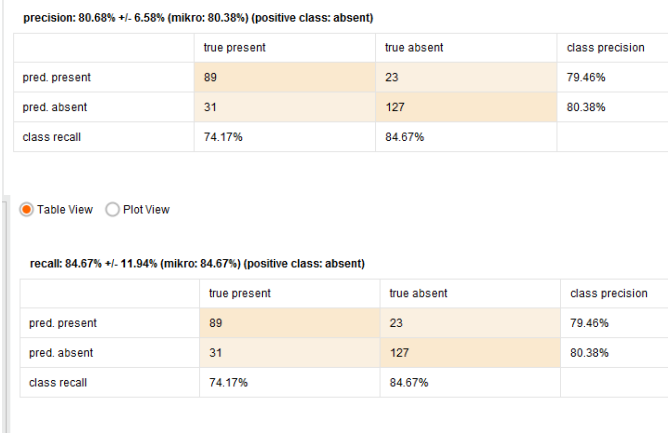

Gambar 13. Hasil Pengujian Nilai Precision, Recall dari algoritma C4.5-PSO

Hasil yang ditunjukan pada gambar diatas menunjukan evaluasi kinerja metode yang diusulkan dilakukan dengan menghitung parameter uji berupa precision dengan nilai $80.60 \%$, recall dengan nilai $84.67 \%$ dihitung dengan menggunakan rumus:

Precision $=\frac{t p}{t p+f n}$

Recall $=\frac{t p}{t p+f p}$

\section{b. Analisa Evaluasi dan Validasi Hasil}

Hasil dari pengujian model yang dilakukan adalah memprediksi pemasaran langsung dengan support vector machine(SVM), C4.5 berbasis particle swarm optimization(PSO) untuk menentukan nilai accuracy dan AUC (Area Under Curve). Model klasifikasi bisa dievaluasi berdasarkan kriteria seperti tingkat akurasi, kecepatan, kehandalan, skalabilitas dan interpretabilitas (Vecellis, 2009).

Hasil analisis pengujian perhitungan Accuracy dan AUC dari metode algoritma SVM-PSO dan C4.5-PSO dirangkumkan dalam tabel dibawah ini.

Tabel 3 : Tabel perbandingan nilai Accuracy dan AUC

\begin{tabular}{|c|c|c|}
\hline \multirow{2}{*}{ NILAI } & SVM-PSO & C4.5-PSO \\
Accuracy & $\mathbf{8 4 , 8 1 \%}$ & $80.00 \%$ \\
\cline { 2 - 3 } AUC & $\mathbf{0 . 8 9 8}$ & 0.787 \\
\hline
\end{tabular}

Keterangan: Nilai Accuracy dan AUC terbaik disajikan dalam huruf tebal.

Berikut adalah hasil yang akan ditampilkan dalam bentuk grafik untuk menunjukan nilai Accuracy dan AUC dari kedua metode yang dibandingkan dari hasil pengujian.

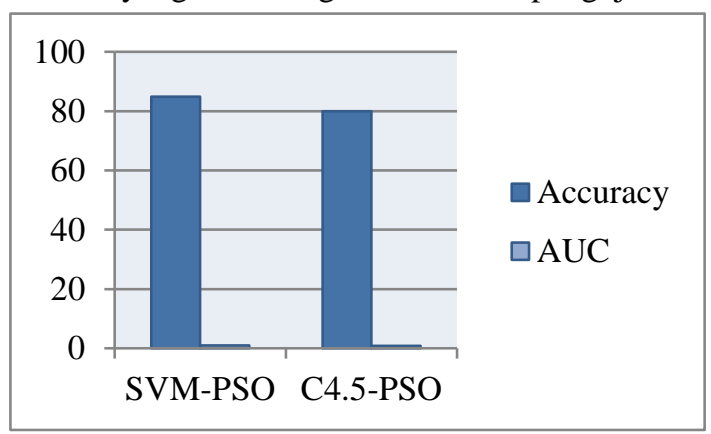

Gambar 14. Grafik tingkat komparasi nilai accuracy dan $\mathrm{AUC}$

Hasil yang ditujukan grafik pada gambar 14, dapat dinyatakan bahwa hasil dari metode klasifikasi berfokus pada nilai Accuracy dan AUC pada masing-masing metode.

Hasil evaluasi kinerja metode yang diusulkan dilakukan dengan menghitung parameter uji berupa precision, recall dan $f$ measure. Secara umum precision, recall dan $f$ measure dihitung dengan menggunakan rumus:

Precision $=\frac{t p}{t p+f n}$

Recall $=\frac{t p}{t p+f p}$

F-Measure $=2 x \frac{\text { precision } * \text { recall }}{\text { precision }+ \text { recall }}$

Tabel 4 : Nilai perbandingan Precision, Recall, $F$-measure

\begin{tabular}{|l|c|c|c|}
\hline Algoritma & Precision & Recall & $\begin{array}{l}\boldsymbol{F} \text { - } \\
\text { measure }\end{array}$ \\
SVM-PSO & $\mathbf{8 0 . 8 4}$ & $\mathbf{9 6 . 6 7}$ & $\mathbf{8 8 . 0 4 9}$ \\
\hline C4.5-PSO & 80.6 & 84.67 & 82.584 \\
\hline
\end{tabular}


INFORM T IKA

Jurnal Informatika, Manajemen dan Komputer, Vol. 13, No. 2, Desember 2021

eISSN : 2580-3042

pISSN : 1979-0694

Berdasarkan hasil eksperimen dan analisis data dalam penelitian ini, maka dapat diperoleh perbandingan nilai Accuracy dan Area Under Curve (AUC) tertinggi pada pengujian model SVM-PSO. Terdapat keunggulan metode SVMPSO terhadap metode pembanding C4.5-PSO, sesudah dilakukan optimasi parameter dengan tahap pengujian.

Hasil uji coba menunjukan SVM-PSO secara rata-rata memiliki kinerja yang lebih baik dibandingkan dengan metode pembanding C4.5PSO dalam aspek nilai Accuracy dan Area Under Curve (AUC) dan beberapa nilai Precision, Recall dan F-Measure.

\section{KESIMPULAN}

Dalam analisis data untuk dataset yang berdimensi besar, klasifikasi sangat diperlukan dalam memprediksi dari sebuah dataset, dalam penelitian ini membandingkan suatu metode untuk mengklasifikasi data yang besar yang dimana data tesebut akan di olah untuk mendapatkan hasil informasi prediksi data yang di inginkan. Dari eksperimen yang di lakukan algoritma SVM-PSO mendapatkan nilai Accuracy $84.81 \%$ dan nilai AUCnya 0.898 sedangkan Algoritma C4.5-PSO mendapatkan nilai Accuracy $80.00 \%$ dan nilai AUCnya 0.787.

Dari hasil eksperimen dan pengujian yang sudah dilakukan dapat disimpulkan metode algoritma SVM-PSO lebih baik dibandingkan C4.5-PSO dalam prediksi data penyakit jantung.

\section{REFERENSI}

Abraham, A., Grosan, C., \& Ramos, V. (2006). Swarm Intelligence in Data Mining. Springer.

Gorunescu, F. (2011). Data mining: concepts and techniques. In Chemistry \&amp; https://doi.org/10.1007/978-3-642-19721-5

Jiawei, H., Kamber, M., Han, J., Kamber, M., \& Pei, J. (2012). Data Mining: Concepts and Techniques. In San Francisco, CA, itd: Morgan Kaufmann https://doi.org/10.1016/B978-0-12-3814791.00001-0

Kim, J., Choi, K., Kim, G., \& Suh, Y. (2012). Classification cost: An empirical comparison among traditional classifier,
Cost-Sensitive Classifier, and MetaCost. Expert Systems with Applications, 39(4), 4013-4019.

https://doi.org/10.1016/j.eswa.2011.09.071

Lee, Y., \& Lee, J. (2015). Binary tree optimization using genetic algorithm for multiclass support vector machine. Expert Systems with Applications, 42(8), 38433851.

https://doi.org/10.1016/j.eswa.2015.01.022

Liu, Y., Yu, X., Huang, J. X., \& An, A. (2011). Combining integrated sampling with SVM ensembles for learning from imbalanced datasets. Information Processing and Management, 47(4), 617-631. https://doi.org/10.1016/j.ipm.2010.11.007

Witten, I. H., Frank, E., \& Hall, M. a. (2011). Data Mining Practical Machine Learning Tools and Techniques Third Edition. In Data Mining (Vol. 277, Issue Tentang Data Mining). https://doi.org/10.1002/15213773(20010316)40:6<9823::AIDANIE9823>3.3.CO;2-C

Yin, Y., Han, D., \& Cai, Z. (2011). Explore Data Classification Algorithm Based on SVM and PSO for Education Decision. Journal of Convergence Information Technology, 6(10), 122-128. https://doi.org/10.4156/jcit.vol6.issue10.16

Yu, X., Guo, S., Guo, J., \& Huang, X. (2011). An extended support vector machine forecasting framework for customer churn in e-commerce. Expert Systems with Applications, 38(3), 1425-1430. https://doi.org/10.1016/j.eswa.2010.07.049

Zaki, M. J., Meira, W., \& Jr. (2014). Data Mining and Analysis: Fundamental Concepts and Algorithms. 562. https://books.google.com/books?hl=en\&lr= \&id=Gh9GAwAAQBAJ\&pgis=1 